dr hab. inż. Henryk Radomiak, prof. P. Cz. ${ }^{1}$

mgr inż. Marlena Mazur ${ }^{1}$

dr hab. inż. Monika Zajemska, prof. P. Cz. ${ }^{1}$

dr inż. Dorota Musiał ${ }^{1}$

Przyjęty/Accepted/Принята: 18.02.2015;

Zrecenzowany/Reviewed/Рецензирована: 23.11.2015;

Opublikowany/Published/Опубликована: 31.12.2015;

\title{
Gaszenie płomienia dyfuzyjnego przy pomocy fal akustycznych ${ }^{2}$
}

\author{
Extinguishing a diffusion flame with the aid of acoustic waves
}

Тушение диффузионного пламени с помощью акустических волн

\begin{abstract}
A B S T R AKT
Cel: W artykule przedstawiono możliwości wygaszania płomienia dyfuzyjnego za pomocą fal akustycznych. Wyznaczono krytyczną wartość częstotliwości oraz graniczną moc akustyczną, przy których zachodzi zjawisko wygaszenia płomienia.

Metody: Na potrzeby realizacji zamierzonego celu niezbędne było skonstruowanie stanowiska umożliwiającego generowanie fal akustycznych w kierunku palnika. Stanowisko wyposażono w generator częstotliwości oraz wzmacniacz sygnału, głośnik o niskim paśmie przewodzenia, falowód, a także mierniki: napięcia, natężenia i częstotliwości. Pomiaru ciśnienia akustycznego w miejscu usytuowania płomienia dokonano za pomocą sondy Culite. Sonda jest skonstruowana na zasadzie mikrofonu z bardzo czułą membraną, elektrodą oraz kondensatorem. Zmiana ciśnienia w ośrodku powoduje minimalne przesunięcie membrany, co w konsekwencji powoduje zmiany w poziomie naładowania kondensatora. Poziom ten jest rejestrowany jako zmiana napięcia przepływającego przez układ. Wartości tego napięcia obserwuje się na ekranie systemu pomiarowego, co pozwala na przeliczenie ich na wartości ciśnienia, uwzględniając zakres pracy systemu pomiarowego. Ponadto wykonano wizualizację przebiegu procesu wygaszania płomienia za pomocą aparatu smugowego. Jest to idealna metoda graficznego dokumentowania wyników badań prowadzonych nad procesami spalania, gdzie niedostateczne oświetlenie wyciemnionego otoczenia nie pozwala na prawidłowe zobrazowanie tradycyjnymi metodami, zaś przy otoczeniu oświetlonym zachodzi nieoddanie całej struktury płomienia na zdjęciu, wywołane mocnym światłem emitowanym przez płomień.

Wyniki: Przeprowadzone badania dowiodły, że dla danej wartości mocy cieplnej płomienia możliwe jest jego wygaszenie za pomocą szerokiego spektrum częstotliwości krytycznej $(35 \div 155 \mathrm{~Hz})$ oraz poziomu mocy granicznej poniżej $30 \mathrm{~W}$. Zdolność gaśniczą oszacowano, wyznaczając współczynnik skuteczności gaszenia płomienia - dla wartości $35 \div 45 \mathrm{~Hz}$ mieściła się ona w przedziale od $35 \mathrm{do} 155 \mathrm{~Hz}$. Ponadto wyznaczono graniczną wartość ciśnienia akustycznego (zakres $45 \div 55 \mathrm{~Pa}$ ), poniżej której zjawisko wygaszania płomienia było praktycznie niezauważalne.

Wnioski: Przedstawiona metoda gaszenia płomienia umożliwia, poprzez zadziałanie falą akustyczną o odpowiedniej częstotliwości, całkowite wygaszenie płomienia. Fakt ten potwierdzają uzyskane w ramach eksperymentów wyniki, jak również przeprowadzona wizualizacja za pomocą aparatu smugowego.
\end{abstract}

Słowa kluczowe: pożar, gaszenie płomienia, płomień dyfuzyjny, fala akustyczna

Typ artykułu: oryginalny artykuł naukowy

\section{A B S T RACT}

Aim: The paper presents the feasibility of extinguishing a diffusion flame with the aid of acoustic waves. The study includes an assignment of critical frequency values and the acoustic force limit, the point at which a flame is extinguished.

Methods: In order to achieve the desired aim, it was necessary to construct a test stand, to facilitate the generation of acoustic waves in the direction of a burner. The experimental stand was equipped with a frequency generator and amplifier, speaker with a low frequency band, waveguide and voltage strength and frequency meters. Measurement of sound pressure at the flame location was performed using a Culite probe. The probe was constructed on the principle of a microphone, using a very sensitive membrane, electrode and capacitor.

Politechnika Częstochowska / Czestochowa University of Technology; henrad@wip.pcz.pl;

2 Autorzy wnieśli jednakowy wkład merytoryczny w powstanie artykułu / The authors contributed equally to this article; 
Changing the pressure within the probe resulted in a minimal displacement of the membrane, which in turn caused changes to the charge level of the capacitor. This level was recorded as a change in the voltage flowing through the system. The voltage value was revealed on the screen of the measuring device, which allowed for the calculation of pressure values, taking into account the operating range of the measuring device. Additionally, extinguishing of the flame was observed visually with the aid of Schlieren imagery apparatus. This is considered to be an ideal method for graphical recording of research results associated with the combustion processes where insufficient lighting of a dim environment does not allow for proper imaging, using traditional methods. Whereas, in ambient lit conditions it is not possible to reveal the entire structure of the flame because of strong light emitted by the flame.

Results: Studies reveal that for a given value of flame thermal power it is possible to extinguish a flame with the use of a wide spectrum of critical frequency $(35 \div 155 \mathrm{~Hz})$ and force limit level below $30 \mathrm{~W}$. Extinguishing ability was estimated by assigning a flame extinguishing effectiveness ratio; for the value of $35 \div 45 \mathrm{~Hz}$ it was within the range between 35 to $155 \mathrm{~Hz}$. Additionally, the sound pressure level limit value (range of $45 \div 55 \mathrm{~Pa}$ ) was assigned, below which the flame extinguishing activity was virtually unnoticeable.

Conclusions: The described flame extinguishing technique allows for the total extinguishing of flames with the aid of generated sound waves at an appropriate frequency. This is confirmed by results from research experiments and visual observation, using Schlieren imagery apparatus.

Keywords: fire, extinguishing a flame, diffusion flame, acoustic wave

Type of article: original scientific article

\section{АННОТАЦИЯ}

Цель: Эта статья представляет возможность тушения диффузионного пламени с помощью акустических волн. Определено критическую частоту и предел акустической мощности, при которых возникает явление тушения пламени.

Методы: Для того чтобы достичь поставленной цели, необходимо было построить установку для генерации акустических волн в направлении горелки. Установку оборудовано в генератор частоты и усилитель, громкоговоритель с низкой зоной проводимости, волновод и измерительные приборы: напряжения, интенсивности и частоты. Измерение акустического давления в месте расположения пламени было выполнено с использованием зонда Culite. Зонд построен на основе микрофона с очень чувствительной мембраной, электроду и конденсатором. Изменение давления в среде приводит к минимальному смещению мембраны, что следовательно вызывает изменения на уровне заряда конденсатором. Этот уровень записывается как изменение напряжения, проходящего через систему. Значения этого напряжения можно наблюдать на экране измерительной системы, что позволяет пересчитать их на значения давления, принимая во внимание диапазон работы измерительной системы. Кроме того, сделано визуализацию процесса тушения пламени с помощью Шлирен-аппарата ИАБ-451. Это идеальный метод для использования графической документации результатов исследования, проведенного на процессы горения, где недостаточное освещение затемненной среды не позволяет его правильно изображать традиционными методами, в то время как для освещенной среды на фотографии происходит неполное изображение всей структуры пламени, вызванное острым светом, излучаемым пламенем.

Результаты: Исследование показало, что для данной тепловой мощности пламени существует возможность его угасания с помощью широкого спектра критической частоты $(35 \div 155$ Ги) и предельного уровня мощности ниже 30 W. Эффективность тушения определена фактором, определяющим эффективность тушения пламени при величине $35 \div 45$ Ги, была расположена в диапазоне от 35 до 155 Ги. Кроме того, установлен предел звукового давления (диапазон $45 \div 55$ Па), ниже которого тушение пламени было практически незаметно.

Выводы: Предложенный метод тушения пламени позволяет, при воздействии акустической волны соответствующей частоты, полностью потушить огонь. Этот факт подтверждается результатами экспериментов, а также визуализации, выполненных с помощью тШлирен-аппарата ИАБ-451.

Ключевые слова: огонь, тушить пламя, диффузионная пламя, акустическая волна

Вид статьи: оригинальная научная статья

\section{Wprowadzenie}

Już od wielu lat poszukuje się skutecznych sposobów wygaszania pożarów. Mimo prowadzenia w tej dziedzinie badań na szeroką skalę, nadal nie przyniosły one oczekiwanych rezultatów w postaci nowych metod gaszenia pożarów. Wbrew postępowi nauki i techniki, w chwili obecnej za najskuteczniejszy sposób ochrony przed pożarami uznaje się rozsądne obchodzenie się $\mathrm{z}$ ogniem, natomiast do ich gaszenia używa się przeważnie tradycyjnych środków gaśniczych, w szczególności wody [1-3]. Jak wskazują wyniki badań przeprowadzonych zarówno w kraju [3-7], jak i poza jego granicami [2], [8-11], przyszłościową metodą walki z ogniem może być fala akustyczna.

Istota procesu wygaszania płomienia za pomocą fali akustycznej oparta jest na mechanizmie wygaszania płomienia za pomocą jego rozciągania [12-13]. Turbulencje wartości jednego z parametrów otoczenia, wpływając na wektor prędkości propagacji frontu płomienia, zmieniają jego kierunek, rozciągając go, co z kolei powoduje zwiększoną emisję ciepła do momentu przekroczenia granicy palności [12], [14]. O wpływie dźwięku na przebieg procesu spalania świadczą wyniki eksperymentów prowadzonych już od 2008 roku przez Agencję Zaawansowanych Obronnych Projektów Badawczych DARPA (Defense Advanced Research Projects Agency). Do badań wykorzystano podpalone paliwo płynne oraz dwa głośniki ułożone po obu jego stronach. Na zamieszczonym na portalu internetowym [2] krótkim filmiku z przebiegu tego eksperymentu widać, że w momencie odtwarzania dźwięku płomień słabnie, a następnie zachodzi zjawisko rozpraszania się płomienia, które również wspomaga ugaszenie ognia. Z przeprowadzonych przez DARPA testów wynika, że fala dźwiękowa, poprzez zwiększenie prędkości ruchu 
powietrza na brzegach płomienia, powoduje zmniejszenie obszaru, na którym pożar występuje. Zaobserwowane zjawisko może mieć istotny wpływ na osłabienie płomienia, a tym samym może się przyczynić do całkowitego jego ugaszenia. Dodatkowym spostrzeżeniem podczas przeprowadzonych przez DARPA testów był fakt, że dźwięk wykorzystany do gaszenia płomienia nie musi być głośny, ale musi być odpowiednio modulowany. Świadczą o tym badania przeprowadzone przez Węsierskiego i innych [4]. W swoich badaniach wykazali, że istotny jest nie tylko dobór odpowiedniej częstotliwości dźwięku podczas gaszenia pożaru, ale również sposób skupienia wiązki na możliwie najmniejszym obszarze.

Zaproponowana w niniejszym artykule metoda gaszenia płomienia, na obecnym etapie znajomości technologiil, nie jest możliwa do zastosowania w przypadku większych pożarów, zwłaszcza w otwartej przestrzeni.
Mogłaby natomiast być pomocna podczas gaszenia pożarów w zamkniętych pomieszczeniach, takich jak np. kokpit samolotu [2], a nawet mogłaby wspomagać, na zasadzie stałych urządzeń gaśniczych, bezpieczeństwo magazynów, hal przemysłowych, czy zbiorników cieczy palnych [4].

Zamieszczone w niniejszym artykule wybrane badania wygaszania płomienia falą akustyczną zostały wykonane na potrzeby realizacji pracy inżynierskiej pod kierunkiem jednego $\mathrm{z}$ autorów [15].

\section{Stanowisko pomiarowe}

W celu wyznaczenia częstotliwości krytycznej, granicznej mocy akustycznej, a także wizualizacji procesu wygaszania płomienia za pomocą aparatu smugowego, skonstruowano stanowisko pomiarowe przedstawione na ryc. 1.

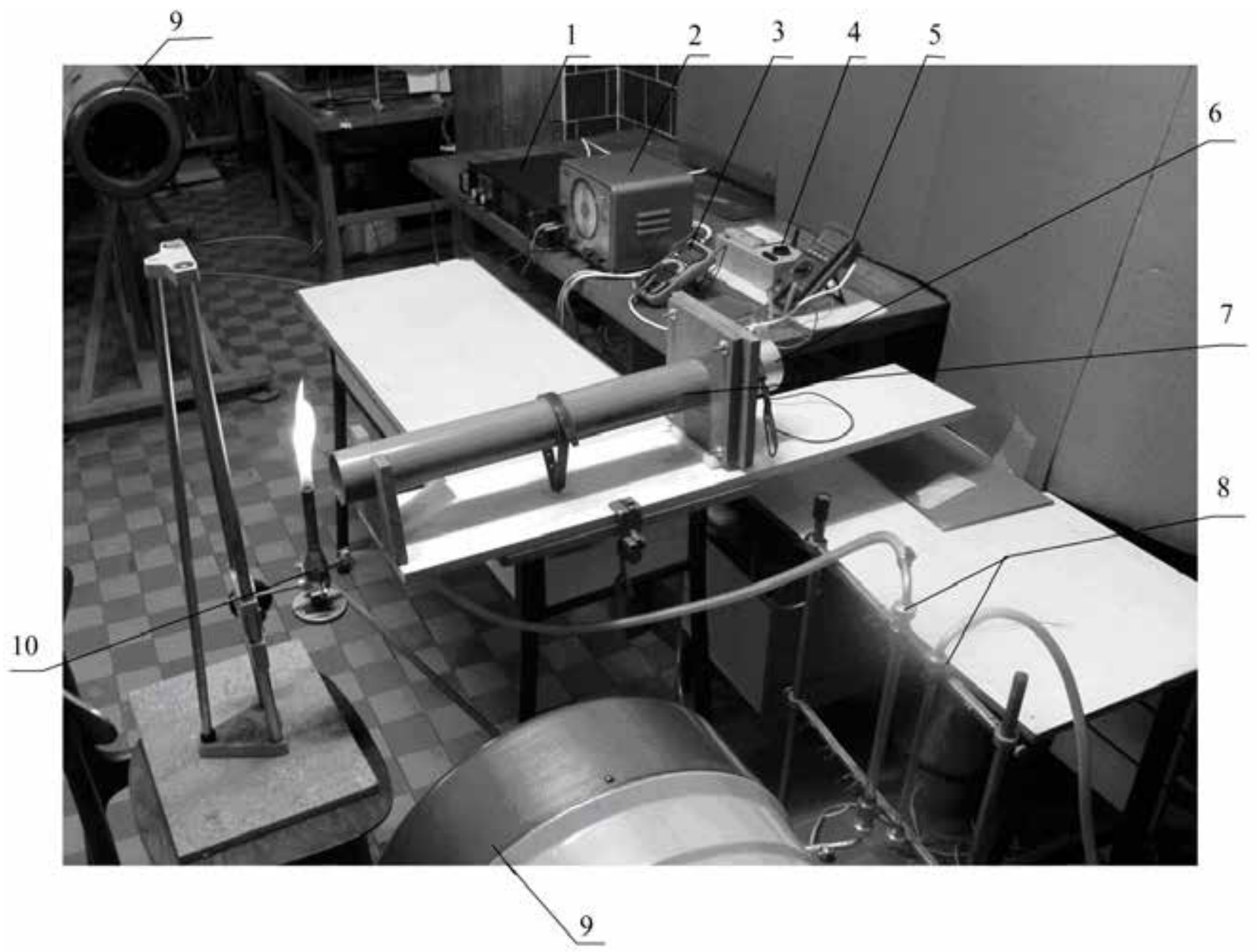

Ryc. 1. Układ do generacji fali akustycznej: 1 - wzmacniacz, 2 - generator, 3 - mierniki, 4 - falowód, 5 - płomień Fig. 1. Mechanism for generation of acoustic wave: 1 - amplifier, 2 - generator, 3 - gauges, 4 - waveguide, 5 - burner Źródło: Opracowanie własne. Source: Own elaboration.

Układ pomiarowy składał się z:

- wzmacniacza Mosfet MDD. 2108M,

- generatora częstotliwości TESLA RC OSCILATOR BM 365U,

- mierników cyfrowych:
- BRYMEN BM805 jako miernik częstotliwości,

- KYORITSU MODEL 1009 jako woltomierz,

- miernika analogowego ГОСТ 10374-82 jako amperomierz,

- głośnika SONY 1-825-378-11, 
- tunelu aerodynamicznego o wymiarach $1=0,65 \mathrm{~m}$, $\varphi=0,07 \mathrm{~m}$,

- rotametrów,

- aparatu smugowego,

- palnika o średnicy dyszy $\varphi_{d y s z y}=0,0168 \mathrm{~m}$.

Badania ciśnienia akustycznego w miejscu usytuowania płomienia dokonano za pomocą sondy Culite.

Istotnym elementem analizy procesu spalania jest wizualizacja tego procesu. Podczas realizacji ww. metody badawczej naukowcy często borykają się z problemem niedostatecznego oświetlenia w wyciemnionym otoczeniu. Przy otoczeniu oświetlonym struktura płomienia nie może być oddana na zdjęciu całkowicie ze względu na własne silne światło. Aby wyeliminować te problemy, zastosowano tzw. metodę cieniową, która wykorzystuje zmiany we współczynniku załamania światła przy występowaniu zmian gęstości, co powoduje inny kąt ugięcia promienia świetlnego.

\section{Wyniki i dyskusja}

Badania wstępne przeprowadzono w celu określenia mocy podawanej na głośnik. Dla częstotliwości z zakresu $35 \div 155 \mathrm{~Hz}$ przeprowadzono kolejne serie pomiarowe na wybranych czterech poziomach napięć odniesienia (ryc. 2).

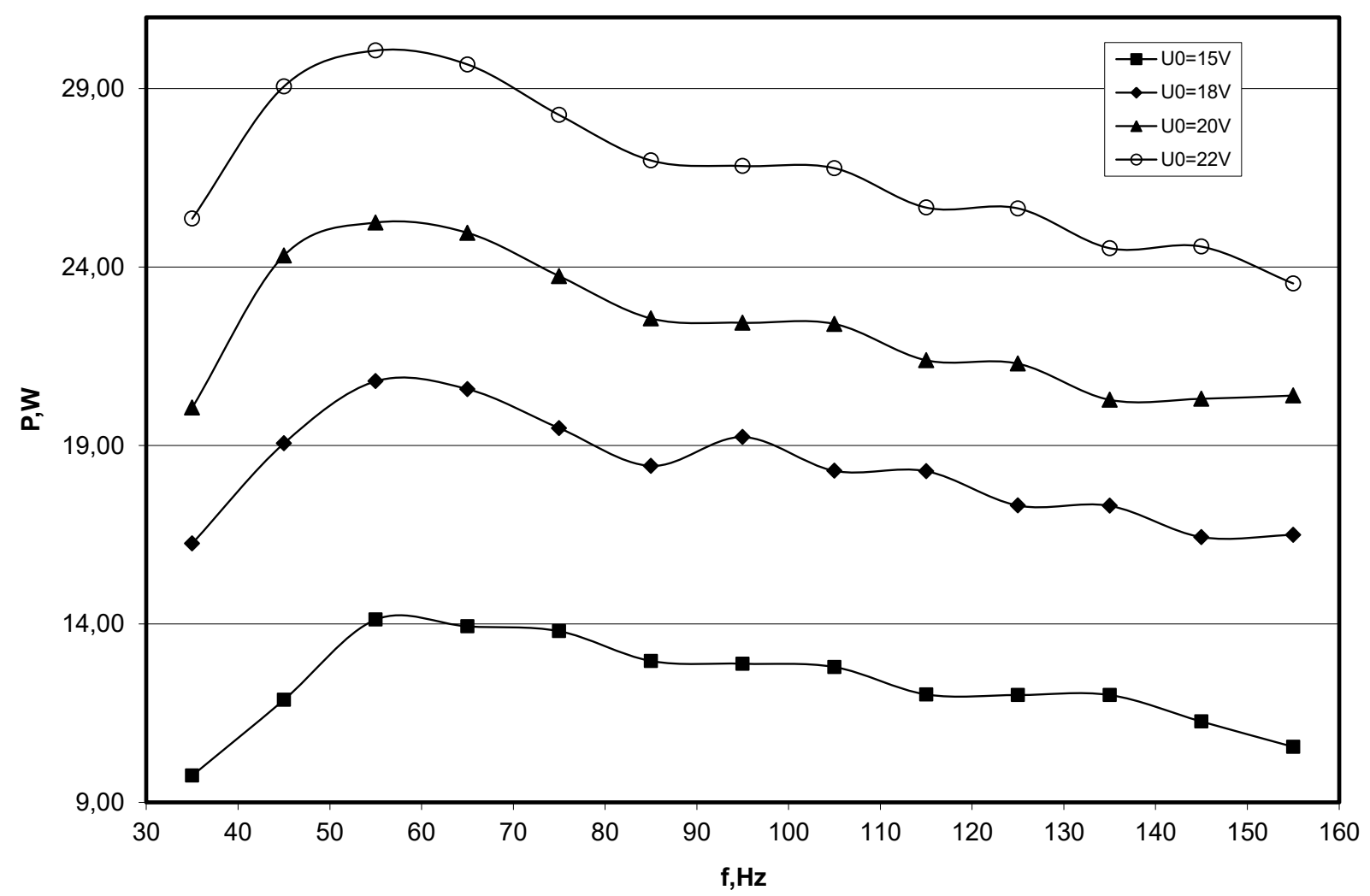

Ryc. 2. Zależność mocy głośnika od częstotliwości

Fig. 2. Relationship between loudspeaker's power and frequency

Źródło: Opracowanie własne.

Source: Own elaboration.

Z przedstawionych na ryc. 2 przebiegów mocy głośnika w funkcji częstotliwości w zakresie od 35 do $155 \mathrm{~Hz}$ widać, że istotny wpływ na wartość mocy ma napięcie odniesienia. Największą moc głośnika zaobserwowano dla częstotliwości największej tj. odpowiednika napięcia U0 $=22 \mathrm{~V}$, natomiast najmniejszą dla częstotliwości $\mathrm{U} 0=15 \mathrm{~V}$, tj. najmniejszej z analizowanych częstotliwości. Ponadto można zauważyć pewien powtarzający się dla wszystkich badanych poziomów napięcia odniesienia charakter krzywych, a mianowicie: początkowo moc głośnika rośnie, osiągając maksimum dla wartości częstotliwości równej $55 \mathrm{~Hz}$, a następnie maleje dla całego przedziału analizowanej częstotliwości.

Istotnym zagadnieniem jest określenie skuteczności wygaszania płomienia w zależności od odległości płaszczyzny wylotu falowodu od czoła płomienia. W tym celu zbadano zależność ciśnienia akustycznego od częstotliwości fali akustycznej w różnych odległościach od wylotu falowodu. Wyniki pomiarów przedstawiono na ryc. 3 i 4. 


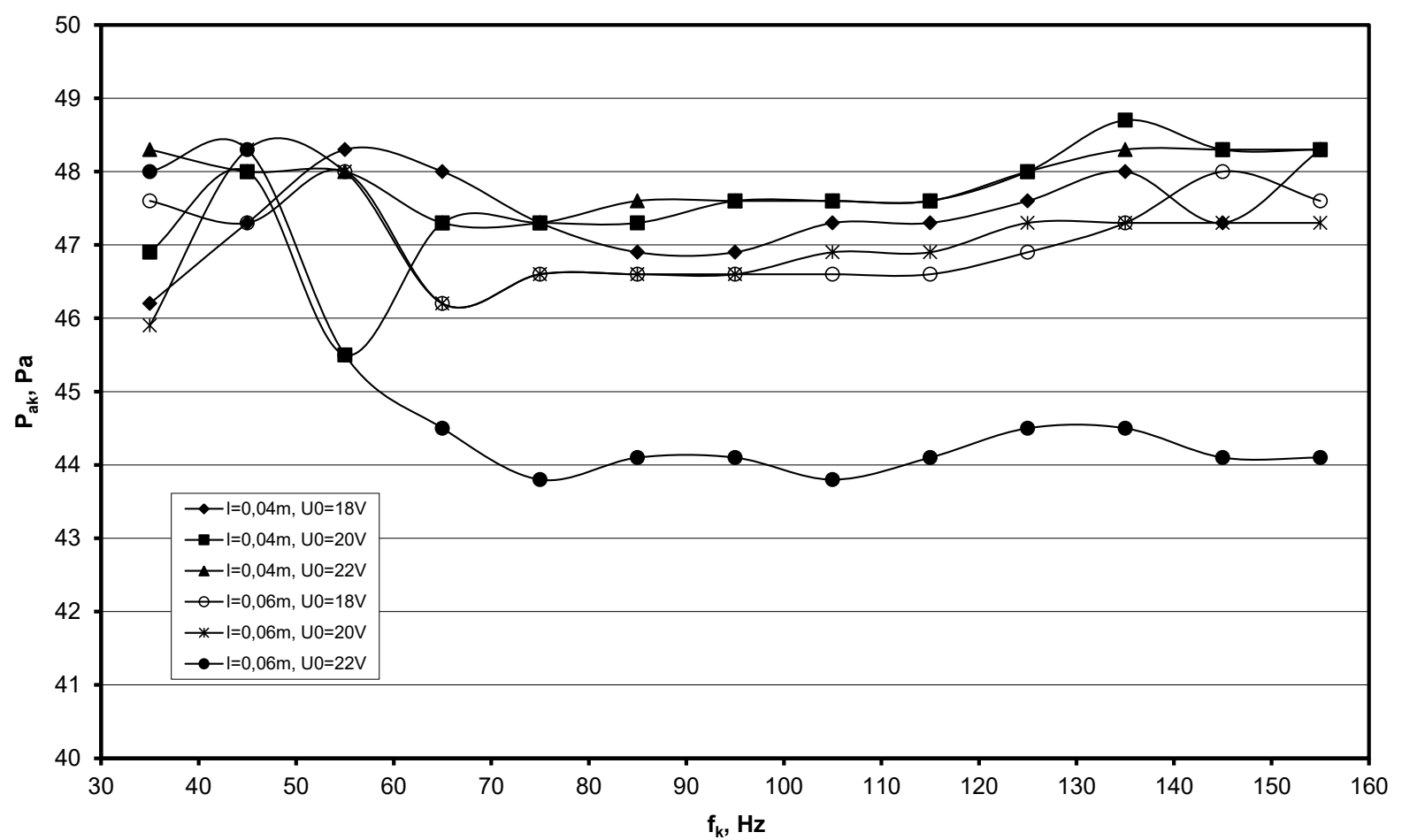

Ryc. 3. Zależność poziomu ciśnienia akustycznego od częstotliwości fali, $1=0$ i $0,02 \mathrm{~m}$

Fic. 3. Relationship between acoustic pressure and wave frequency, $1=0$ and $0.02 \mathrm{~m}$

Źródło: Opracowanie własne.

Source: Own elaboration.

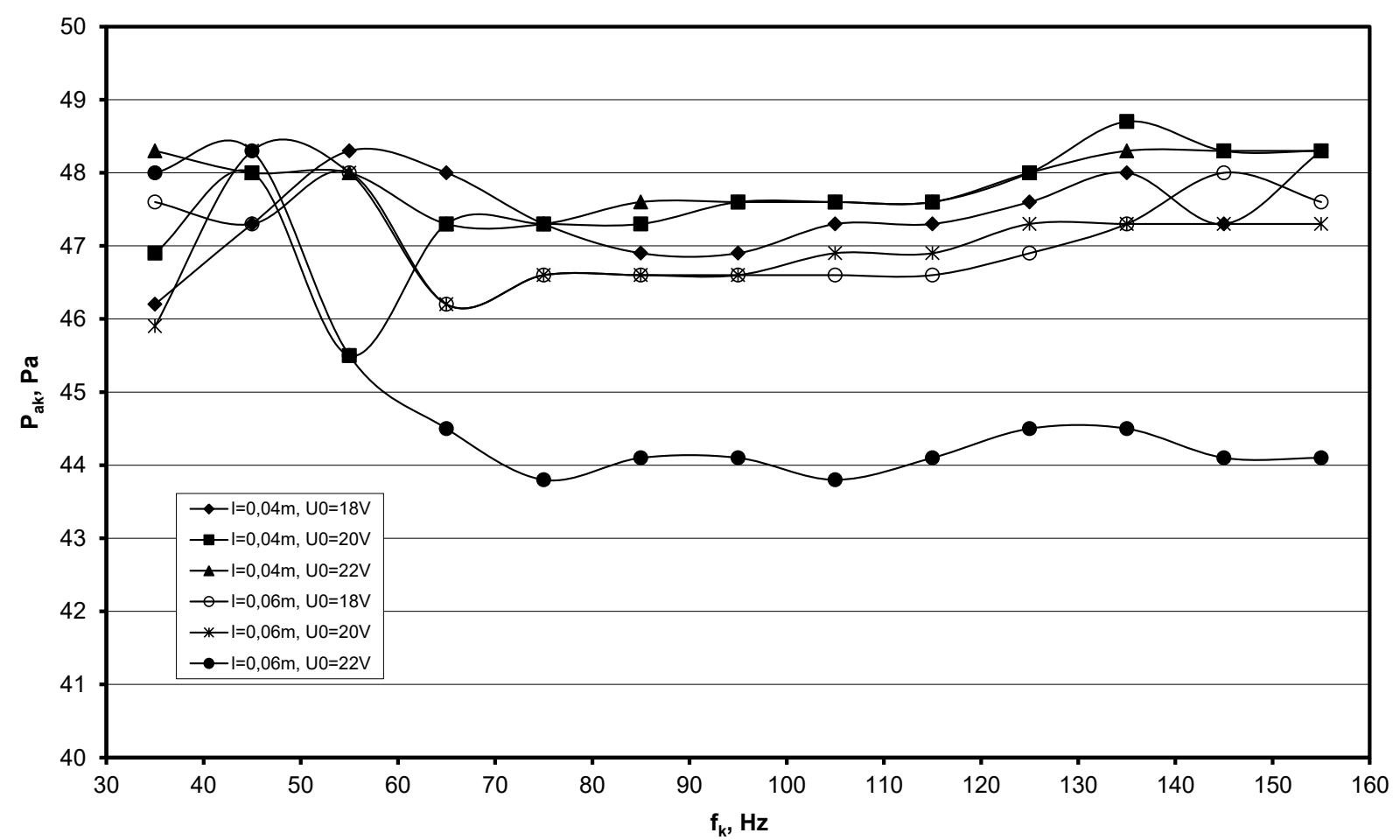

Ryc. 4. Zależność poziomu ciśnienia akustycznego od częstotliwości fali, $1=0,04$ i 0,06 m

Fig. 4. Relationship between acoustic pressure and wave frequency, $\mathrm{l}=0.04$ and $0.06 \mathrm{~m}$

Źródło: Opracowanie własne.

Source: Own elaboration.

Podczas analizy przedstawionych na ryc. 3 i 4 zależności można zauważyć nieznaczne różnice w wartości ciśnienia dla kolejnych częstotliwości. Podobnie jest z wartościami ciśnienia akustycznego dla różnych poziomów napięcia 
początkowego - niezależnie od tej wartości, poziom ciśnienia akustycznego jest porównywalny. Różnice można dostrzec dopiero między wartością ciśnienia akustycznego dla danej, dowolnie wybranej częstotliwości fali i odległości od płaszczyzny wylotu tunelu aerodynamicznego. Tendencja ta jest wyraźnie malejąca. Dlatego też w przeprowadzanych badaniach często wygaszał się płomień znajdujący się blisko powierzchni wylotu tunelu aerodynamicznego, a niemożliwe stawało się ugaszenie tego samego płomienia, oddalonego o pewną odległość. Może być to spowodowane niedostatecznym poziomem turbulencji poziomu ciśnienia, co nie prowadziło do wystarczającego rozciągnięcia płomienia, a następnie jego wygaszenia.

W tabelach 1-4 przedstawiono wartości częstotliwości krytycznej $\left(\mathrm{f}_{\mathrm{k}}\right)$ oraz mocy granicznej $\left(\mathrm{P}_{\mathrm{g}}\right)$, przy których nastąpiło zjawisko zgaszenia płomienia. Pomiar przeprowadzono przy stałej wartości strumienia gazu $\left(\mathrm{V}_{g}=100 \mathrm{l} / \mathrm{h}\right)$ dla wartości częstotliwości w zakresie $35 \div 155 \mathrm{~Hz}$, co $5 \mathrm{~Hz}$, w ściśle określonych odległościach od wylotu tunelu aerodynamicznego, aż do wartości $1=0,06 \mathrm{~m} . \mathrm{W}$ tabelach zamieszczono również współczynnik skuteczności wygaszania płomienia (k), który stanowi porównanie mocy cieplnej płomienia oraz mocy granicznej. Moc cieplną płomienia dyfuzyjnego obliczono wykorzystując równanie Simona i Wagnera [8]:

$$
\begin{aligned}
P_{p}= & \frac{Q}{V_{p l}} W_{d} \\
P_{p}= & \frac{27,778 \cdot 10^{-6} \frac{\mathrm{m}^{3}}{\mathrm{~s}}}{\frac{1}{3} \cdot \pi \cdot \frac{0,0168^{2}}{2} \mathrm{~m}^{2} \cdot 0,301 \mathrm{~m}} \cdot 35 \cdot 10^{6} \frac{\mathrm{J}}{\mathrm{m}^{3}} \\
P_{p}= & 43,74 \cdot 10^{6} \frac{\mathrm{W}}{\mathrm{m}^{3}}
\end{aligned}
$$

gdzie: $W_{d}$ - wartość opałowa gazu ziemnego, $\mathrm{J} / \mathrm{m}^{3}$;

$Q$ - natężenie przepływu paliwa, $\mathrm{m}^{3} / \mathrm{s}$;

$V_{p l}$ - objętość płomienia, $\mathrm{m}^{3}$.

\begin{tabular}{|c|c|c|c|c|}
\hline $\begin{array}{l}\mathbf{f}_{\mathrm{k}}, \\
\mathrm{Hz}\end{array}$ & $\begin{array}{l}\mathrm{U}, \\
\mathrm{V}\end{array}$ & I, & $\begin{array}{l}\mathbf{P}_{\mathrm{g}}, \\
\mathrm{W}\end{array}$ & $\begin{array}{l}\mathbf{k}=\mathbf{P}_{\mathrm{g}} / \mathbf{P}_{\mathrm{p}} \\
{ }^{\star} 10^{-4} \mathbf{m}^{3}\end{array}$ \\
\hline 35 & 6,77 & 0,10 & 0,68 & 1,55 \\
\hline 40 & 6,99 & 0,15 & 1,05 & 2,40 \\
\hline 45 & 7,94 & 0,20 & 1,59 & 3,64 \\
\hline 50 & 8,16 & 0,30 & 2,45 & 5,60 \\
\hline 55 & 10,74 & 0,50 & 5,37 & 12,28 \\
\hline 60 & 9,52 & 0,45 & 4,28 & 9,79 \\
\hline 65 & 10,16 & 0,50 & 5,08 & 11,61 \\
\hline 70 & 11,56 & 0,65 & 7,51 & 17,17 \\
\hline 75 & 12,89 & 0,75 & 9,67 & 22,11 \\
\hline 80 & 14,59 & 0,85 & 12,40 & 28,35 \\
\hline 85 & 17,15 & 1,05 & 18,01 & 41,18 \\
\hline 90 & 16,63 & 1,00 & 16,63 & 38,02 \\
\hline 95 & 19,72 & 1,20 & 23,66 & 54,09 \\
\hline 100 & 24,85 & 1,40 & 34,79 & 79,54 \\
\hline 105 & 18,35 & 1,10 & 20,19 & 46,16 \\
\hline 110 & 21,87 & 1,30 & 28,43 & 65,00 \\
\hline 115 & 22,25 & 1,30 & 28,93 & 66,14 \\
\hline 120 & 20,07 & 1,20 & 24,08 & 55,05 \\
\hline 125 & 23,23 & 1,30 & 30,20 & 69,04 \\
\hline 130 & 23,30 & 1,30 & 30,29 & 69,25 \\
\hline 135 & 23,47 & 1,30 & 30,51 & 69,75 \\
\hline 140 & 22,68 & 1,25 & 28,35 & 64,81 \\
\hline 145 & 23,70 & 1,25 & 29,63 & 67,74 \\
\hline 150 & 23,45 & 1,40 & 32,83 & 75,06 \\
\hline 155 & 22,70 & 1,20 & 27,24 & 62,28 \\
\hline
\end{tabular}

Tabela 1. Wartości $\mathrm{f}_{\mathrm{k}}, \mathrm{P}_{\mathrm{g}}$ oraz $\mathrm{k}$ dla odległości $\mathrm{l}=0 \mathrm{~m}$

Table 1. The values $\mathrm{f}_{\mathrm{k}}, \mathrm{P}_{\mathrm{g}}$ and $\mathrm{k}$ for the distance $\mathrm{l}=0 \mathrm{~m}$

Źródło: Opracowanie własne.

Source: Own elaboration. 
Tabela 2. Wartości $\mathrm{f}_{\mathrm{k}}, \mathrm{P}_{\mathrm{g}}$ oraz $\mathrm{k}$ dla odległości $\mathrm{l}=0,02 \mathrm{~m}$

Table 2. The values $f_{k}, P_{g}$ and $k$ for the distance $l=0,02 \mathrm{~m}$

\begin{tabular}{|c|c|c|c|c|}
\hline $\begin{array}{l}f_{k}, \\
H z\end{array}$ & $\begin{array}{l}\mathrm{U} \\
\mathrm{V}\end{array}$ & $\begin{array}{l}\text { I, } \\
\text { A }\end{array}$ & $\begin{array}{l}\mathbf{P}_{\mathrm{g}}, \\
\mathbf{W}\end{array}$ & $\begin{array}{l}\mathbf{k}=\mathbf{P}_{\mathrm{g}} / \mathbf{P}_{\mathrm{p}} \\
{ }^{\star} 10^{-4} \mathrm{~m}^{3}\end{array}$ \\
\hline 35 & 7,21 & 0,10 & 0,72 & 1,65 \\
\hline 40 & 7,41 & 0,15 & 1,11 & 2,54 \\
\hline 45 & 9,42 & 0,35 & 3,30 & 7,54 \\
\hline 50 & 9,44 & 0,40 & 3,78 & 8,64 \\
\hline 55 & 11,09 & 0,55 & 6,10 & 13,95 \\
\hline 60 & 12,80 & 0,75 & 9,60 & 21,95 \\
\hline 65 & 13,39 & 0,80 & 10,71 & 24,49 \\
\hline 70 & 14,01 & 0,95 & 13,31 & 30,43 \\
\hline 75 & 15,76 & 1,00 & 15,76 & 36,03 \\
\hline 80 & 17,55 & 1,10 & 19,31 & 44,15 \\
\hline 85 & 19,19 & 1,15 & 22,07 & 50,46 \\
\hline 90 & 20,49 & 1,25 & 25,61 & 58,55 \\
\hline 95 & 22,22 & 1,30 & 28,89 & 66,05 \\
\hline 100 & 22,56 & 1,30 & 29,33 & 67,06 \\
\hline 105 & 24,99 & 1,45 & 36,24 & 82,85 \\
\hline 110 & 22,82 & 1,30 & 29,67 & 67,83 \\
\hline 115 & 23,47 & 1,35 & 31,68 & 72,43 \\
\hline 120 & 24,87 & 1,40 & 34,82 & 79,61 \\
\hline
\end{tabular}

Źródło: Opracowanie własne.

Source: Own elaboration.

Tabela 3. Wartości fk, Pg oraz k dla odległości $1=0,04 \mathrm{~m}$

Table 3. The values $\mathrm{fk}, \mathrm{Pg}$ and $\mathrm{k}$ for the distance $\mathrm{l}=0,04 \mathrm{~m}$

\begin{tabular}{|c|c|c|c|c|}
\hline $\begin{array}{c}\mathbf{f}_{\mathbf{k}} \\
\mathbf{H z}\end{array}$ & $\mathbf{U}$, & $\mathbf{I}$, & $\begin{array}{c}\mathbf{P}_{\mathbf{g}} \\
\mathbf{W}\end{array}$ & $\begin{array}{c}\mathbf{k}=\mathbf{P}_{\mathbf{g}} / \mathbf{P}_{\mathbf{p}} \\
{ }^{*} \mathbf{1 0}^{-4} \mathbf{m}^{3}\end{array}$ \\
\hline 35 & $\mathbf{V}$ & 0,15 & 1,31 & 2,99 \\
\hline 40 & 10,14 & 0,30 & 3,04 & 6,95 \\
\hline 45 & 11,54 & 0,50 & 5,77 & 13,19 \\
\hline 50 & 12,97 & 0,65 & 8,43 & 19,27 \\
\hline 55 & 14,79 & 0,85 & 12,57 & 28,74 \\
\hline 60 & 15,44 & 0,90 & 13,90 & 31,78 \\
\hline 65 & 18,24 & 1,10 & 20,06 & 45,86 \\
\hline 70 & 24,55 & 1,50 & 36,83 & 84,20 \\
\hline 75 & 25,56 & 1,50 & 38,34 & 87,65 \\
\hline
\end{tabular}

Źródło: Opracowanie własne.

Source: Own elaboration.

Tabela 4. Wartości $\mathrm{f}_{\mathrm{k}}, \mathrm{P}_{\mathrm{g}}$ oraz $\mathrm{k}$ dla odległości $\mathrm{l}=0,06 \mathrm{~m}$

Table 4. The values $f_{k}, P_{g}^{g}$ and $k$ for the distance $l=0,06 \mathrm{~m}$

\begin{tabular}{|c|c|c|c|c|}
\hline $\begin{array}{l}\mathbf{f}_{\mathbf{k}} \\
\mathbf{H z}\end{array}$ & $\begin{array}{l}\text { U, } \\
\text { V }\end{array}$ & $\begin{array}{l}\text { I, } \\
\text { A }\end{array}$ & $\begin{array}{l}\mathbf{P}_{\mathrm{g}} \\
\stackrel{\mathrm{W}}{ }\end{array}$ & $\begin{array}{l}\mathbf{k}=\mathbf{P}_{\mathrm{g}} / \mathbf{P}_{\mathrm{p}} \\
{ }^{\star} 10^{-4} \mathbf{m}^{3}\end{array}$ \\
\hline 35 & 14,75 & 0,6 & 8,85 & 20,23 \\
\hline 40 & 17,17 & 0,7 & 12,02 & 27,48 \\
\hline
\end{tabular}




\begin{tabular}{|c|c|c|c|c|}
\hline $\mathbf{f}_{\mathbf{k}}$ & $\mathbf{U}$, & $\mathbf{I}$, & $\mathbf{\mathbf { P } _ { \mathbf { g } }}$ & $\mathbf{W}_{\mathbf{W}}$ \\
$\mathbf{H z}$ & $\mathbf{V}$ & $\mathbf{A}$ & $\mathbf{\mathbf { P }} / \mathbf{P}_{\mathbf{p}}$ \\
\hline 45 & 22,07 & 1,3 & 28,69 & 65,59 \\
\hline 50 & 26,14 & 1,5 & 36,60 & 83,68 \\
\hline 55 & 30,74 & 1,8 & 43,11 & 98,56 \\
\hline
\end{tabular}

Źródło: Opracowanie własne.

Source: Own elaboration.

Dla płomienia o danej mocy cieplnej, współczynnik $\mathrm{k}$, będący stosunkiem mocy granicznej i mocy płomienia, jest związany w sposób funkcyjny z częstotliwością krytyczną (ryc. 5). Funkcja ta, w większej części zbadanej dziedziny (w granicach $35 \div 155 \mathrm{~Hz}$ ), jest funkcją rosnącą, co wskazuje na wzrost mocy granicznej dla zwiększających się częstotliwości. Dla częstotliwości krytycznej, których wartości zbliżają się do granic wyznaczonego przedziału badawczego, funkcja nieznacznie zmienia swoją monotoniczność, osiągając minimum w okolicach $\mathrm{f}_{\mathrm{k}}=35 \div 45 \mathrm{~Hz}$. Warto zauważyć również fakt, że wartości stosunku mocy granicznej do mocy płomienia rosną przy zwiększaniu odległości płomienia od płaszczyzny wylotu tunelu aerodynamicznego.

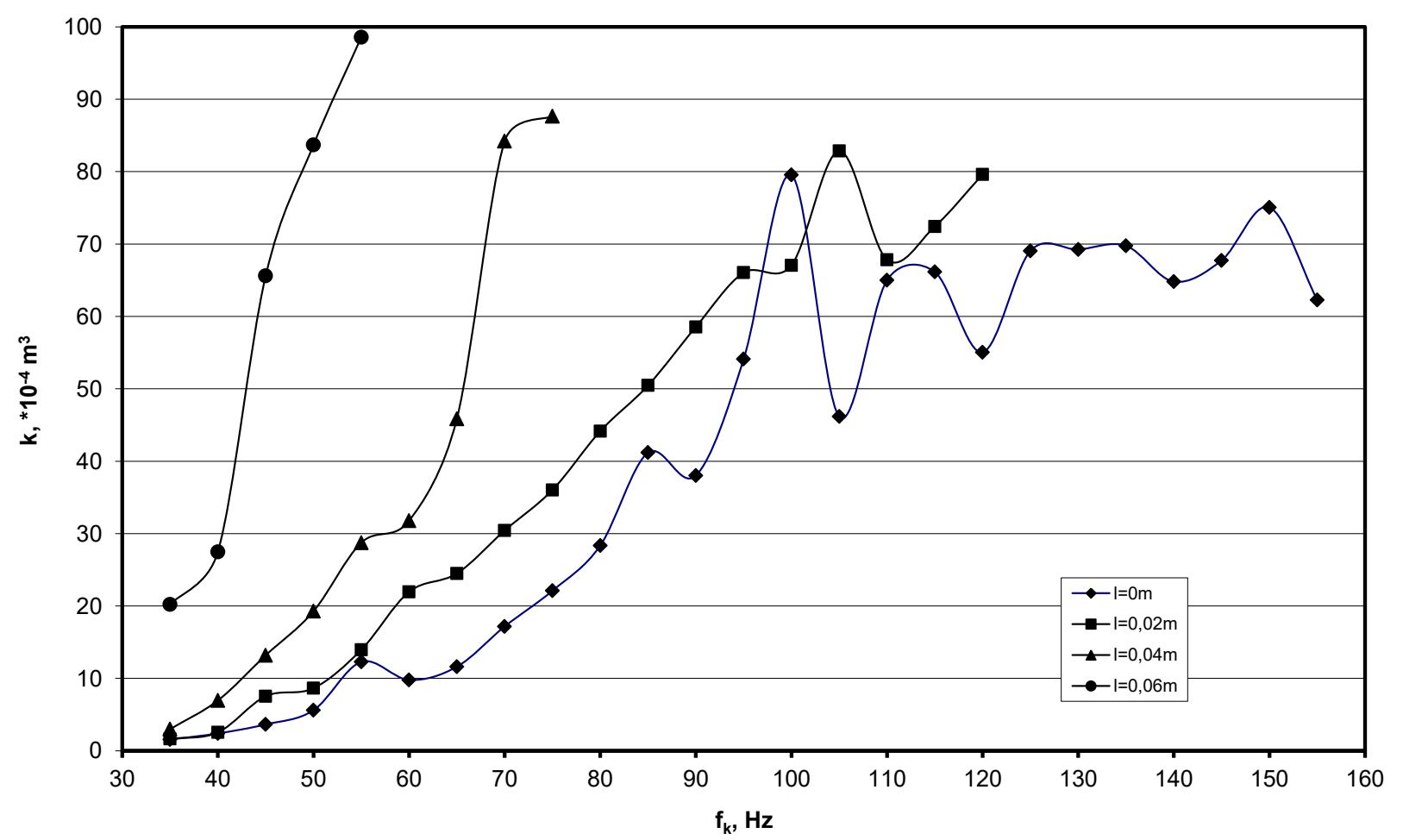

Ryc. 5. Zależność współczynnika k od częstotliwości krytycznej, dla płomienia o mocy cieplnej $43,74^{\star} 10^{6} \mathrm{~W} / \mathrm{m}^{3}$ Fig. 5. Coefficient $\mathrm{k}$ as a function of critical frequency, the flame of thermal power $43.74^{\star} 10^{6} \mathrm{~W} / \mathrm{m}^{3}$

Źródło: Opracowanie własne.

Source: Own elaboration.

Zaobserwowano również różnice między wartościami współczynnika k w zależności od mocy cieplnej płomienia. W badaniach przeprowadzonych przez Węsierskiego i innych [4] wykazano, iż dla mocy płomienia znajdującej się w zakresie wartości $1,32 \div 6,08 \times 10^{6} \mathrm{~W} / \mathrm{m}^{3}$, i częstotliwości krytycznej $40 \mathrm{~Hz}$, wartość współczynnika $\mathrm{k} \approx 3,77 \times 10^{-6} \mathrm{~m}^{3}$. Rozbieżność między wyżej wymienioną wartością, a wynikami otrzymanymi w tych badaniach może wynikać z dużych różnic w objętości badanych płomieni (w szczególności średnicy dyszy palnika), a także $\mathrm{z}$ różnic wartości natężenia przepływu paliwa (za czym idzie zmiana objętości płomienia).
Jak już wcześniej wspomniano, niezmiernie istotna jest analiza procesu spalania $\mathrm{z}$ wykorzystaniem metod wizualizacji. Niezdolność oka ludzkiego do obserwacji odpowiednich zmian zachodzących podczas wygaszania płomienia oraz niedokładność powszechnie dostępnych przyrządów optycznych (aparat fotograficzny, kamera), wyrażająca się podczas pracy z obiektami świecącymi, wymusiła konieczność przeprowadzenia wizualizacji procesu wygaszania płomienia za pomocą aparatu smugowego. $\mathrm{Na}$ ryc. 6 przedstawiono wizualizację wygaszania płomienia dla wybranej wartości częstotliwości krytycznej i mocy granicznej. 


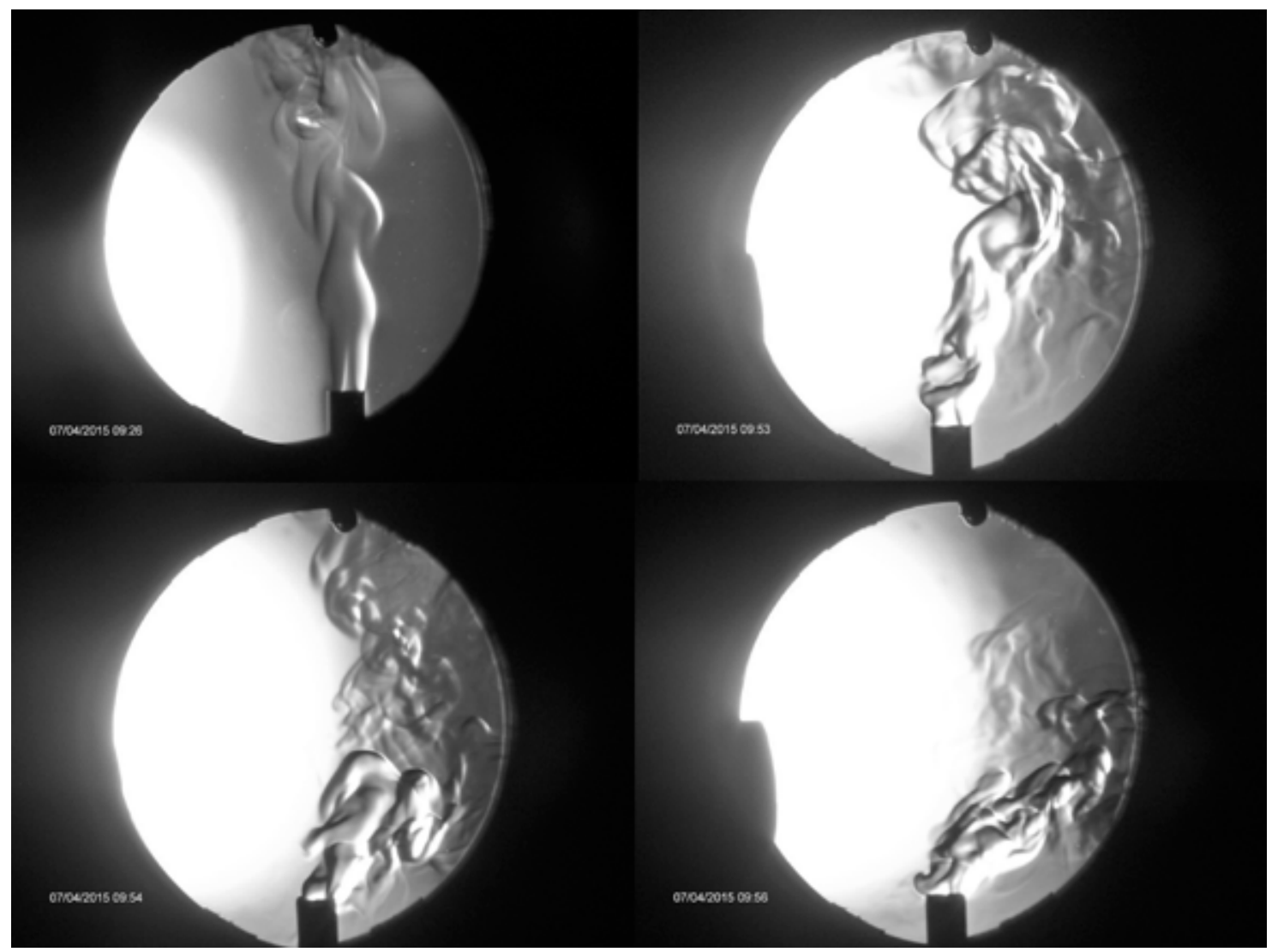

Ryc. 6. Wizualizacja wygaszania płomienia dla $\mathrm{f}_{\mathrm{k}}=35 \mathrm{~Hz}$ i $\mathrm{P}_{\mathrm{g}}=0,68 \mathrm{~W}$

Fig.6. Visualization of the process of extinguishing the flame for $\mathrm{f}_{\mathrm{k}}=35 \mathrm{~Hz}$ and $\mathrm{P}_{\mathrm{g}}=0.68 \mathrm{~W}$

Źródło: Opracowanie własne.

Source: Own elaboration.

Z przedstawionej na ryc. 6 wizualizacji z użyciem aparatu smugowego widać wyraźnie, jak płomień pod działaniem fali akustycznej rozprasza się i słabnie, a następnie gaśnie.

\section{Wnioski}

Wykazano, że dla danej wartości mocy cieplnej płomienia możliwe jest wygaszenie go za pomocą szerokiego spektrum częstotliwości krytycznej $(35 \div 155 \mathrm{~Hz})$ oraz poziomem mocy granicznej poniżej $30 \mathrm{~W}$. Badania przeprowadzano dla różnych odległości od płaszczyzny wylotu tunelu aerodynamicznego.

Turbulencją zaburzającą front płomienia może być poziom ciśnienia akustycznego, zmieniający się sinusoidalnie. Za jego graniczną wartość, poniżej której trudno było zaobserwować zjawisko wygaszania płomienia, można przyjąć zakres $45 \div 55 \mathrm{~Pa}$, w zależności od odległości płomienia od płaszczyzny wylotu tunelu aerodynamicznego.

Wyznaczony współczynnik skuteczności gaszenia płomienia jest zależnością funkcyjną, która przyjmuje minimum lokalne (dla przedziału $35 \div 155 \mathrm{~Hz}$ ) dla wartości $35 \div 45 \mathrm{~Hz}$. Świadczy to o największej zdolności gaśniczej wartości krytycznych znajdujących się w tym przedziale wartości.

Wyniki przedstawionych badań mogą znaleźć zastosowanie w systemach gaśniczych, zwłaszcza w miejscach, w których ilość środków gaśniczych jest ograniczona (np. pokłady samolotów podczas lotu), jak i w przypadku pożarów substancji, których właściwości nie pozwalają na gaszenie ich konwencjonalnymi metodami. Problematyczne pozostaje jednak stwierdzenie wpływu tak niskich częstotliwości na organizm ludzki oraz opracowanie technologii pozwalającej na jak najdokładniejsze dotarcie do źródła ognia.

\section{Literatura}

[1] Wilczkowski S., Poszukiwanie nowych sposobów gaszenia pożarów, „BiT Nauka i Technika Pożarnicza”, Vol. 30 Issue 2, 1988.

[2] Czarczyńska K., Gaszenie ognia dźwiękiem. DARPA pokazuje, jak użyć głośników do walki z pożarem, http:// gadzetomania.pl/5335, gaszenie-ognia-dzwiekiem-darpa-pokazuje-jak-uzyc-glosnikow-do-walki-zpozarem [dostęp 11 lutego 2014].

[3] Wilczkowski S., Środki gaśnicze, Szkoła Aspirantów PSP, Kraków 1995.

[4] Węsierski T., Wilczkowski S., Radomiak H., Wygaszanie procesu spalania przy pomocy fal akustycznych, BiTP Vol. 30 Issue 2, 2013, pp. 59-64.

[5] Wilczkowski S., Szecówka L., Radomiak H., Mszoro K., Sposób gaszenia płomieni falami akustycznymi, Patent krajowy Nr 177792. 
[6] Leśniak B., Wilczkowski S., Próby zastosowania fal akustycznych do hamowania procesów spalania, „BiT Nauka i Technika Pożarnicza”, Vol. 30 Issue 2, 1988.

[7] Wilczkowski S., Szecówka L., Radomiak H., Mszoro K., Urządzenie do gaszenia falami akustycznymi. Patent krajowy Nr 177478.

[8] Simon D.M., Wagner P., Characteristics of turbulent combustion by flame space and space heating, "Journal of Industrial and Engineering Chemistry”, Issue 1, 1956, p. 129.

[9] Im H.G., Law C.K., Axelbaum R.L., Opening of the burkeschumann flame tip and the effects of curvature on diffusion flame extinction, "Symposium (International) on Combustion 01/1991" Volume 23, Issue 1, 1991, pp. 551-558, DOI: $10.1016 /$ S0082-0784(06)80302-4.

[10] Zambon A.C., Chelliah H.K., Acoustic-wave interactions with counterflow single-and twin-premixed flames: finite-rate kinetics, heat release and phase effects, Proc. Combust. Institute, Volume 31, 2007, 1247-1255.

[11] Lentati A.M., Chelliah H.K., Physical, thermal and chemical effects of fine-water droplets in extinguishing counterflow diffusion flames. Twenty-Seventh Symposium (International) on Combustion, The Combustion Institute, Pittsburg 1998.

[12] Kowalewicz A., Podstawy procesów spalania, Wydawnictwo Naukowo-Techniczne, Warszawa 2000.

[13] Kordylewski W., Spalanie i paliwa, Oficyna Wydawnicza Politechniki Wrocławskiej, Wrocław 2005.

[14] Roczniak M., Fizyka hałasu. Część I. Podstawy akustyki ośrodków gazowych, Wydawnictwo Politechniki Śląskiej, Gliwice 1996.

[15] Mazur M., Gaszenie płomienia falami akustycznymi. Praca inżynierska, Częstochowa 2014.

dr hab. inż. Henryk Radomiak, prof. P.Cz. - kierownik Katedry Pieców Przemysłowych i Ochrony Środowiska Wydziału Inżynierii Produkcji i Technologii Materiałów Politechniki Częstochowskiej. Zajmuje się szeroko pojętym spalaniem paliw i odpadów oraz diagnostyką urządzeń grzewczych. Wielokrotnie nagrodzony nagrodą Rektora PCZ za osiągnięcia naukowe. Jest autorem i współautorem ponad 100 publikacji w czasopismach krajowych i zagranicznych oraz materiałach konferencyjnych. Członek wielu organizacji naukowych, a w szczególności Polskiego Instytutu Spalania.

mgr inż. Marlena Mazur - absolwentka kierunku „Inżynieria Bezpieczeństwa” studiów I stopnia na wydziale Inżynierii Produkcji i Technologii Materiałów Politechniki Częstochowskiej. Obecnie studentka studiów niestacjonarnych stopnia II Wydziału Elektrycznego PCz.

dr hab. inż. Monika Zajemska, prof. P.Cz. - zastępca kierownika Katedry PPiOŚ Wydziału Inżynierii Produkcji i Technologii Materiałów Politechniki Częstochowskiej. Zajmuje się przewidywaniem i ograniczaniem szkodliwych produktów spalania z przemysłowych komór grzewczych, jak również numerycznym modelowaniem ww. procesów. Wielokrotnie nagrodzona nagrodą Rektora PCZ za osiągnięcia naukowe. Jest autorem monografii oraz autorem i współautorem ponad 100 publikacji w czasopismach krajowych i zagranicznych oraz materiałach konferencyjnych. Jest członkiem wielu organizacji naukowych, a w szczególności Polskiego Instytutu Spalania.

dr inż. Dorota Musiał - adiunkt w Katedrze PPiOŚ Politechniki Częstochowskiej. Jest absolwentką Wydziału Inżynierii Procesowej, Materiałowej i Fizyki Stosowanej Politechniki Częstochowskiej (2002). Tytuł doktora z dziedziny Metalurgia otrzymała w 2007 r. Wielokrotnie wyróżniona nagrodą Rektora PCZ za osiągnięcia naukowe. Zainteresowania naukowe: spalanie paliw i odpadów, emisja zanieczyszczeń powietrza, numeryczne modelowanie. Jest autorem i współautorem ponad 60 publikacji w materiałach konferencyjnych, czasopismach krajowych i zagranicznych. 